\title{
Praktik Sosial Pengasuhan Anak Terinfeksi HIV dan AIDS dalam Keluarga di Kota Padang : Studi EnamKeluarga dengan Anak Terinfeksi HIV/AIDS
}

\author{
Muharman, Jendrius, Indradin \\ Magister Sosiologi Unand, Padang, Indonesia \\ muharmanimoe@gmail.com
}

\begin{abstract}
Child Protection Regulation in Indonesia believes the family as the main support system for children with various problems including HIV / AIDS. This policy is based on the view that places the family as the main institution of child protection. Because people with HIV / AIDS are still stigmatized, this is a family challenge to provide care for children with HIV / AIDS. The challenge is between telling the child's HIV / AIDS status to get broader support in care, by avoiding stigmatization. In this dilemma the questions that will be answered in this article are what are parents doing in caring for children infected with HIV / AIDS, how to avoid stigma from the social environment, what social structures are able to block and hinder the quality of care and care. This research uses a qualitative method based on case studies of 6 families with children infected with HIV / AIDS through the mother to child transmission pathway. This article shows that HIV / AIDS infection through mother-to-child transmission can also describe negative parental risk behaviors according to community moral standards. Parents try to hide the infection status of their children from other family members by moving from one place to another. This strategy of avoiding stigmatization does not affect health care and treatment even if their status is known by existing health care units. However, there is anxiety that their child's family will not get their rights to education, social relations and other social support needed for growth and development, if their HIV / AIDS status is opened. Thus the results of this study demanded the reengagement of the family as the main support system for the care and care of children with HIV / AIDS. The limitation of this study is that the children studied are infected from mother to child transmission, so children who are transmitted in other ways have not been revealed by this study.
\end{abstract}

Keywords: Children with HIV/AIDS, Parenting and Caregiving, Family as Support system

FOKUS : Jurnal Kajian Keislaman dan Kemasyarakatan Vol. 4, No. 2, 2019

LPPM Institut Agama Islam Negeri (IAIN) Curup - Bengkulu

Available online: http://journal.staincurup.ac.id/index.php/JF

p-ISSN 2548-334X, e-ISSN 2548-3358 


\begin{abstract}
Abstrak
Regulasi Perlindungan Anak di Indonesia meyakini keluarga sebagai support system utama bagi anak dengan berbagai persoalan termasuk HIV/AIDS. Kebijakan ini didasari oleh pandangan yang menempatkan keluarga sebagai institusi utama perlindungan anak. Karena penderita HIV/AIDS hingga saat ini masih mengalami stigmatisasi, maka ini menjadi tantangan keluarga untuk memberikan pengasuhan anak-anak dengan HIV/AIDS. Tantangan itu adalah antara memberitahu status HIV/AIDS anak untuk mendapatkan dukungan yang lebih luas dalam pengasuhan, dengan menghindari stigmatisasi. Dalam keadaan dilematis ini pertanyaan yang akan dijawab dalam artikel ini adalah apa yang dilakukan oleh orang tua dalam melakukan pengasuhan anak terinfeksi HIV/AIDS, bagaimana menghindari stigma dari lingkungan sosial, struktur sosial apa yang memampungan dan menghalangi kualitas pengasuhan dan perawatan. Penelitan ini mengguankan metode kualitatif berdasarkan studi kasus 6 keluarga dengan anak terinfeksi HIV/AIDS melalu jalur penularan ibu ke anak. Artikel ini menunjukan bahwa infeksi HIV/AIDS melalui penularan ibu ke anak juga dapat menggambarkan perilaku beresiko orang tuanya yang negatif menurut standar moral komunitas. Orang tua berusaha untuk menyembunyikan status infeksi anaknya kepada anggota keluarga yang lain dengan cara berpindahpindah tempat tinggal. Strategi menghindar dari stigmatisasi ini tidak mempengaruhi pelayanan kesehatan dan pengobatan sekalipun status mereka diketahui oleh unit pelayan kesehatan yang ada. Akan tetapi terdapat kecemasan keluarga anak mereka tidak mendapat hak-hak nya atas pendidikan, hubungan sosial dan dukungan sosial lainnya yang diperlukan untuk tumbuh kembang, jika status HIV/AIDS mereka dibuka. Dengan demikian hasil studi ini menuntut penalaahan ulang keluarga sebagai support system utama bagi pengasuhan dan perawatan anak dengan HIV/AIDS. Keterbatasan studi ini adalah anak-anak yang diteliti adalah yang terinfeksi dari faktor penularan ibu ke anak, sehingga anak-anak yang penularan dengan cara yang lain belum terungkap oleh studi ini.
\end{abstract}

Katakunci: Anak dengan HIV/AIDS, Orangtua dan Perhatian, Sistem dukungan keluarga, 


\section{PENDAHULUAN}

Persoalan penularan $\mathrm{HIV}^{1}$ dan $\mathrm{AIDS}^{2}$ di Indonesia saat ini telah menjadi isue prioritas penanganan masalah kesehatan di Indonesia. Salah satu yang menarik untuk di kaji dalam persoalan ini adalah penularan HIV dan AIDS pada kelompok anak, baik yang ditularkan melalui ibu ke bayi yang dikandungnya maupun melalui proses penularan lainnya. Penanganan kasus HIV dan AIDS pada anak berbeda dengan penanganan kasus HIV dan AIDS pada individu dewasa. Jika menggunakan asumsi perlindungan anak, maka anak-anak pengidap HIV dan AIDS dalam undang-undang dikategorikan kedalam kelompok anak yang mendapatkan perlindungan khusus (Undang-Undang No. 23 tahun 2002 tentang Perlindungan Anak), oleh karena itu dibutuhkan pula upaya-upaya yang secara khusus, sistematis dan komprehensif dalam menangani permasalahan ini.

Dalam buku Laporan Tahunan Dinas Kesehatan Kota Padang tahun 2017 memperlihatkan bahwa jumlah kasus HIV/AIDSpada tahun 2015 sebanyak 227 kasus HIV dan 81 kasus AIDS. Sementara itu pada tahun 2016 jumlah ini meningkat menjadi 300 kasus HIV dan 56 AIDS. Dari data ini terlihat bahwa kasus HIV bertambah sebanyak 73 kasus dan terjadi kematian pada pengidap AIDS.

Bila menggunakan definisi kelompok usia anak adalah individu usia dibawah 18 tahun (berdasarkan Konvensi Hak Anak dan Undang-Undang Nomor 23 tahun 2001 tentang Perlindungan Anak) maka perkembangan jumlah anak pengidap HIV pada kelompok usia anak di Kota Padang dapat dilihat dalam tabel 1 di bawah ini.

Tabel 1 Data Kasus HIV Pada Kelompok Usia Anak Tahun 2018 di Kota Padang

\begin{tabular}{|c|c|c|}
\hline Kelompok Usia & Laki-laki & Perempuan \\
\hline$<4$ tahun & 5 & 7 \\
\hline $5-14$ tahun & 12 & 3 \\
\hline 15-19 tahun & 4 & 1 \\
\hline Jumlah & 21 & 11 \\
\hline
\end{tabular}

Sumber : Profil Kesehatan Kota Padang 2018

Jumlah ini hanyalah kasus yang dilaporkan dan mendapatkan pelayanan dari institusi kesehatan, masih diyakini terdapat sejumlah kasus

\footnotetext{
${ }^{1}$ HIV (Human Imunne Deficiency Virus) adalah virus yang menyebabkan hilangnya sistem kekebalan tubuh.

${ }^{2}$ AIDS (Aquired Immune Deficiency Syndrome) kumpulan gejala penyakit sebagai akibat menurunnya sistem kekebalan tubuh.
} 
yang tidak terdeteksi atau tidak dilaporkan karena berbagai faktor sosial seperti banyak keluarga yang masih menganggap bahwa HIV adalah aib keluarga, ada yang tidak tahu harus melaporkan kemana atau ada yang merasa bahwa dirinya tidak tertular karena belum memperlihatkan tandatanda fisik yang khas yang dalam bahasa medisnya dikenal dengan periode jendela.

Penularan HIV dari ibu yang terinfeksi HIV ke bayinya juga cenderung meningkat seiring dengan meningkatnya jumlah perempuan HIV positif yang tertular baik dari pasangan maupun akibat perilaku yang berisiko. Meskipun angka prevalensi dan penularan HIV dari ibu ke bayi masih terbatas, jumlah ibu hamil yang terinfeksi HIV cenderung meningkat. Prevalensi HIV pada ibu hamil diproyeksikan meningkat dari 0,38\% (2012) menjadi $0,49 \%$ (2016), dan jumlah ibu hamil HIV positif yang memerlukan layanan PPIA ${ }^{3}$ secara otomatis juga akan meningkat.

Besarnya peluang penularan HIV dari ibu ke anak juga terlihat dari hasil kajian paruh waktu Komisi penanggulangan AIDS Nasional (KPAN) yang menunjukkan perubahan perkembangan epidemi HIV dimana terjadi peningkatan prevalensi pada kelompok populasi kunci lelaki suka lelaki (LSL) dan lelaki beresiko tinggi (LBT) serta ibu rumah tangga. Sedangkan pada kelompok populasi kunci lainnya cenderung menurun. Hal inilah yang disebut dengan epidemi meluas, yaitu apabila prevalensi penularan terdapat pada $1 \%$ pada kelompok ibu hamil (http://www.kebijakanaidsindonesia.net)

Penularan HIV kepada anak yang secara teori di kontribusikan dari proses penularan dari ibu ke anak, berhubungan dengan berbagai fenomena perilaku beresiko yang ada pada hari ini antara lain adanya hubungan dengan meningkatnya kasus pengguna narkoba suntik termasuk kelompok dengan status telah menikah. Untuk diketahui, efektivitas penularan HIV dari ibu bayi adalah sebesar 10-30\%. Artinya dari 100 ibu hamil yang terinfeksi HIV, ada 10 sampai 30 bayi yang akan tertular. Sebagian besar penularan terjadi sewaktu proses melahirkan, dan sebagian kecil melalui plasenta selama kehamilan dan sebagian lagi melalui air susu ibu ${ }^{4}$. Kondisi ini tentu tidak berdiri sendiri, terdapat fakta bahwa penularan HIV dari ibu ke anak ternyata terlebih dahulu ditularkan oleh sang bapak kepada ibu dengan berbagai perilaku beresiko tinggi

Bila melihat hubungan anak dengan keluarga dalam konteks masalah ini, terdapat banyak sekali variasi persoalan anak dengan HIV dan AIDS

\footnotetext{
${ }^{3}$ PPIA (Pencegahan Penularan Ibu ke Anak) program pencegahan peneluaran HIV dari ibu hamil ke anak yang dikandungnya.

${ }^{4}$ Disampaikan dalam pidato pada upacara pengukuhan Zubairi Djoerban sebagai Guru Besar tetap dalam IImu Penyakit Dalam pada Fakultas Kedokteran Universitas Indonesia Jakarta, 20 Desember 2003
} 
antara lain; pertama adalah kasus anak dengan HIV dan AIDS masih memiliki kedua orang tua, kedua, anak dengan HIV dan AIDS yang tidak lagi memiliki orang tua, ketiga, anak dengan HIV dan AIDS salah satu orang tuanya meninggal dunia, keempat, anak dengan HIV dan AIDS yang tertular melalui perilaku beresiko si anak, kelima, anak dengan HIV dan AIDS yang tertular dari ibu hamil ke janinnya. Paling tidak terdapat lima variasi kondisi kehidupan kasus anak terinfeksi HIV dan AIDS yang tentu saja akan mempengaruhi bagaimana respon dan pengasuhan dilakukan terhadap anak. Sayangnya tidak banyak hasil penelitian atau kajian yang bicara soal bagaimana pengasuhan dalam keluarga dilakukan terhadap anak pengidap HIV dan AIDS. Hasil penelusurun yang peneliti lakukan pada sejumlah koleksi online perpustakaan di beberapa universitas ternama di Indonesia, memperlihatkan bahwa penelitian terkait HIV dan AIDS yang ada lebih banyak membahas persoalan stigma HIV dan AIDS pada kelompokkelompok kunci serta masalah sosial anak yang ditinggal mati oleh orang tua yang terinfeksi HIV dan AIDS.

Anak dalam kondisi HIV dan AIDS berada dalam kondisi penyakit kronis sehingga beresiko mengalami perubahan fisik, psikologis, perilaku dan emosional yang kronis. Pelayanan kesehatan yang diberikan perlu komprehensif dan intensif dari yang dibutuhkan oleh anak lain pada umumnya (James \& Ashwill, 2007). Ketidakpastian serta ketergantunga pada perawatan dan pengobatan menimbulkan perasaan tidak berdaya dan bingung pada anak dan anggota keluarga atau keluarga pengasuh lainnya, terutama terkait masa depan (Allen \& Marshall, 2008:359).

Dampak yang ditimbulkan akibat HIV dan AIDS dapat muncul pada anak maupun anggota keluarga lainnya, termasuk dampak terhadap aspek ekonomi, pendidikan, kesehatan dan dalam jangka waktu yang panjang dampak terhadap tumbuh kembang anak yang dapat mempengaruhi struktur keluarga (Ritcher, 2004).

Penelitian Ivonne Junita, FIK Universitas Indonesia, 2012 yang berjudul Pengalaman Keluarga Merawat Anak dengan HIV dan AIDS yang menjalani Terapi $\mathrm{ARV}^{5}$ Pada Klinik $\mathrm{VCT}^{6}$ di RSUA Manokwari Provinsi Papua Barat, menyimpulkan bahwa paling tidak terdapat 2 fase situasi yang dialami oleh keluarga manakala mengetahui anak mereka mengidap HIV dan AIDS. Pertama, adalah fase rasa takut. Rasa takut ini sesungguhnya disebabkan oleh ketiadaan pengetahuan, sikap dan keterampilan yang memadai dari keluarga tentang HIV dan AIDS. Tidak paham tentang bagaimana proses penularan, perawatan serta aspek sosial lainnya yang

\footnotetext{
${ }^{5}$ ARV (Obat Anti Retroviral) obat yang diberikan kepada pengidap HIV dan AIDS

${ }^{6} \mathrm{VCT}$ (Voluntary Counseling Test) tatalaksana pra pemeriksaan darah pada orang yang potensi tertular HIV, salah satunya dengan melakukan konseling pra test.
} 
menjadi konsekwensi logis nantinya yang akan dihadapi oleh keluarga. Konsekwensi logis sosial yang paling umum muncul itu adalah terkait stigma negatif terhadap pengidap HIV dan AIDS. Sekalipun sudah banyak upaya advokasi berbagai pihak terkait penghentian stigmatisasi pada pengidap HIV dan AIDS, namun tetap saja hingga hari ini masih terdapat masyarakat yang melekatkan HIV dan AIDS dengan perilaku-prilaku menyimpang.

Fase kedua yang dialami oleh keluarga ketika anaknya didiagnosa mengidap HIV/AIDS antara lain mengalami reaksi emosi pengingkaran, merasa bahwa kenyataan tersebut tidak seharunya terjadi pada mereka, mengapa tidak kepada yang lain. Reaksi pengingkaran tersebut selanjutnya akan berubah menjadi reaksi marah dengan menunjukan perilaku menyalahkan orang lain dan bahkan diri sendiri. Jika kedua reaksi tersebut telah dilewati, maka lama kelamaan akan muncul kesadaran bahwa pengingkaran dan kemarahan tidak akan menyelesaikan masalah, hal ini kemudian berubah menjadi reaksi menerima kenyataan. Hal ini sejalan dengan apa yang disampaikan Yayasan Taratak Jiwa Hati Padang, sebuah yayasan yang bekerja dalam pelayanan ODHA, "seluruh anggota keluarga biasanya mengalami syock mendengar anaknya terinveksi HIV, dan biasanya lama sekali keluarga mau menerima kenyataan tersebut. Kami di yayasan biasanya melakukan pendampingan dan pendekatan secara terus menerus dan kondisi yang paling banyak dibayangkan keluarga adalah masa depan anak".

Keluarga secara sosiologis adalah institusi sosial yang memiliki fungsi perlindungan. Perlindungan maksimal utamanya harus diberikan kepada anggota keluarga yang rentan seperti anak-anak, anggota keluarga yang disabilitas, anggota keluarga yang sakit serta anggota keluarga yang lanjut usia.

Dibutuhkan perawatan dan pengasuhan yang bersifat holistik pada anak pengidap HIV dan AIDS. Holistik dalam hal ini berarti peran atau bantuan yang bersifat utuh, mencakup bantuan pada pemenuhan kebutuhan aspek biologis, psikologis, sosiokultural, dan spiritual dengan segala sifatnya yang hakiki (Potter dan Perry, 2010). Mengembangkan dukungan yang holistik tidaklah mudah dalam hal HIV dan AIDS karena masih terdapat stigmatisasi dalam persoalan ini.

Dengan menggunakan metode kualitatif dan life story maka penelitian iniakan Mengungkap bagaimana gambaran praktik sosial pengasuhan anak yang terinfeksi HIV dan AIDS dalam keluarga di Kota Padang dengan menggunakan studi kasus pada 6 keluarga dengan anak HIV dan AIDS di Kota Padang. Informan penelitian ini adalah keluarga dalam hal ini adalah orang tua yang memiliki anak HIV positif dimana penularan HIV melalui proses penularan vertikal (dari ibu hamil ke anak). Penelusuran informan dilakukan dengan tekhnik snow ball (bola salju) dimana peneliti didampingi 
oleh salah seorang staf dari lembaga swadaya masyarakat yang bekerja untuk program pendamping HIV/AIDS. Informan pertama berhasil dilakukan wawancara setelah dilakukan beberapa kali pendekatan intensif dan untuk informan-informan berikutnya ditelusuri dengan menggunakan informasi dari informan sebelumnya dan dikuatkan melalui data-data yang terdapat di lembaga swadaya masyarakat pendamping penelitian.

\section{PEMBAHASAN}

\section{Gambaran Wilayah Kota Padang}

Kota Padang sebagai Ibu Kota Provinsi Sumatera Barat yang terletakdi pantai barat Pulau Sumatera dan berada antara $0^{\circ} 44^{\prime} 00^{\prime \prime}$ dan $1^{\circ} 08^{\prime}$ 35"lintang selatan dan antara $100^{\circ}$ 05' 05" dan $100^{\circ} 34^{\prime}$ 09" bujur timur.Menurut Peraturan Pemerintah Nomor 17 Tahun 1980, luas Kota Padangadalah $694,96 \mathrm{~km}^{2}$ atau tara dengan $1,65 \%$ dari luas Provinsi sumateraBarat. Kota Padang terdiri dari 11 kecamatan dengan kecamatan terluasadalah Koto Tangah yang mencapai $232,25 \mathrm{~km}^{2}$.

Dari keseluruhan luas Kota Padang sebagian besar (51,01\%) berupa hutan yang dilindungi oleh pemerintah, sedangkan bangunan dan pekarangan adalah seluas $62,88 \mathrm{~km}^{2}(9,05 \%)$ dan yang digunakan untuk lahan persawahan seluas $52,25 \mathrm{~km}^{2}(7,52 \%)$. Sebagai jantung Provinsi Sumatera Barat, Kota Padang berbatasan langsung dengan kabupaten / kota lainnya. Adapun batas-batas wilayah Kota Padang yakni sebelah Utara Kabupaten Padang Pariaman, Sebelah Selatan Kabupaten Pesisir Selatan, Sebelah Barat Kabupaten Solok, Sebelah TimurSamudera Indonesia

Pada tahun 2016 jumlah penduduk Kota Padang mencapai 914.968jiwa, yang berarti terjadi peningkatan dari tahun sebelumnya yang berjumlah902.413 jiwa. Mayoritas masyarakat Kota Padang merupakan suku Minangkabau yang masih memegang nilai-nilai adat dan budaya tradisional. Sekalipun masih memegang nilai adat, akan tetapi masyarakat Kota Padang tetap terbuka terhadap berbagai perubahan sosial, hal ini dapat dilihat dengan tetap rukunnya kehidupan masyarakat padang etnis minangkabau dengan etnis non minangkabau. Mayoritas penduduk masyarakat Kota Padang beragama Islam, selainitu ada juga yang terdapat sebagian masyarakat yang memeluk agama-agam lain seperti Kristen, Hindu, Protestan, Konghuchu dan Budha.

Berdasarkan data dalam buku Profil Kesehatan Kota Padang tahun 2018 ditemukan kasus HIV sebanyak 447 kasus (352 orang laki-laki dan 95 orang perempuan), jumlah ini meningkat dari tahun 2017 (370 orang). Kasus AIDS ditemukan sebanyak103 kasus (79 orang laki laki dan24 orang perempuan), jumlah ini meningkat dari tahun 2017 yaitu sebanyak 93 kasus. Menyikapi ini Pemerintah Kota Padang telah melakukan berbagai upaya, 
selain meningkatkan pengetahuan masyarakat terhadap HIV dan AIDS pada tahun 2017 seluruh puskesmas di Kota Padang telah mampu melakukan pemeriksaan untuk HIV dan AIDS. Selain itu juga telah dikembangkan kerjasama kemitraan dengan klinik dan RSIA agar cakupan tes HIV di puskesmas bisa ditingkatkan, mengoptimalkan peran dan fungsi Komisi Penanggulangan AIDS (KPA) dengan mengintegrasikan lintas sektor dan LSM Peduli AIDS, mengurangi stigma dan diskriminasi terhadap HIV/AIDS pada kelompok resiko tertular, ibu dan anak, memudahkan ODHA untuk memperoleh obat Anti Retroviral (ARV) melalui pelayanan Klinik Voluntary Counseling and Testing (VCT) dan perawatan serta dukungan pengobatan (care, support and Treatment) baik di rumah sakit maupun komunitas (Laporan Tahunan Dinas Kesehatan Kota Padang, 2018).

Dari data penderita HIV dan AIDS yang di lansir oleh Dinas Kesehatan Kota Padang dalam laporan tahunan Dinas Kesehatan Kota Padang tahun 2018 memperlihatkan kasus HIV dan AIDS pada segmen usia anak pada usia anak kurang dari 4 tahun terdapat 9 kasus HIV/AIDS dengan rincian sebanyak 2 orang anak laki-laki dan 7 orang anak perempuan, pada usia 5-14 tahun terdapat 15 kasus HIV/AIDS dengan rincian 3 orang anak laki-laki dan 12 orang anak perempuan sementara pada rentang usia 14-19 tahun terdapat 5 kasus HIV/AIDS dengan rincian 1 orang anak laki-laki dan 4 orang anak perempuan.

Berdasarkan informasi dari kepala Dinas Kesehatan Kota Padang dr. Ferrymulyani Hamid, M.Biomed menyatakan "Dinas Kesehatan kota Padang saat ini melaksanakan triple eliminasi pada kelompok ibu hamil, yaitu pemeriksaan dan penanaganan hepatitis, sifilis dan HIV/AIDS, gunanya adalah untuk menemukenali sedini mungkin apakah calon bayi yang ada dalam kandungan terindikasikan memiliki satu diantara 3 eliminasi tersebut, sehingga pelayanan kesehatan khusus bisa diberikan kepada ibu hamil tersebut"

Dari pernyataan Kepala Dinas Kesehatan Kota Padang di atas, jelas terlihat bahwa pencegahan penularan HIV dari ibu ke anak yang dikandungnya telah menjadi isue strategis yang di kelola oleh Pemerintah Kota Padang dan ini menunjukan bahwa upaya maksimal dilakukan oleh institusi kesehatan untuk dapat emmberikan pelayanan penanganan terhadap kasus-kasus HIv terutama penularan ibu ke anak.

\section{Praktek Sosial Pengasuhan Anak Terinfeksi HIV/AIDS dalam Keluarga Reaksi Emosi}

Status HIV bukanlah sesuatu yang mudah untuk diterima oleh siapapun. Kenyataan bahwa belum ada obat yang mampu mengobati HIV 
adalah sebuah keniscayaan yang memunculkan reaksi yang emosional bagi siapa saja. Dalam penelitian ini seluruh informan menyatakan bahwa mereka melalui fase emosi dimana mengalami shock, menyalahkan keadaan, menyalahkan siapa saja sampai akhirnya pasrah dan menerima kenyataan.

Penelitian Ivonne Junita (2012) dalam penelitiannnya yang berjudul Pengalaman Keluarga Merawat Anak dengan HIV/AIDS yang menjalani Terapi $\mathrm{ARV}^{7}$ Pada Klinik VCT ${ }^{8}$ di RSUA Manokwari Provinsi Papua Barat, menyimpulkan bahwa paling tidak terdapat 2 fase situasi yang dialami oleh keluarga manakala mengetahui anak mereka mengidap HIV/AIDS. Pertama, adalah fase rasa takut. Rasa takut ini sesungguhnya disebabkan oleh ketiadaan pengetahuan, sikap dan keterampilan yang memadai dari keluarga tentang HIV/AIDS. Tidak paham tentang bagaimana proses penularan, perawatan serta aspek sosial lainnya yang menjadi konsekwensi logis nantinya yang akan dihadapi oleh keluarga. Konsekwensi logis sosial yang paling umum muncul itu adalah terkait stigma negatif terhadap pengidap HIV/AIDS. Sekalipun sudah banyak upaya advokasi berbagai pihak terkait penghentian stigmatisasi pada pengidap HIV/AIDS, namun tetap saja hingga hari ini masih terdapat masyarakat yang melekatkan HIV/AIDS dengan perilaku-prilaku menyimpang.

Fase kedua yang dialami oleh keluarga ketika anaknya didiagnosa mengidap HIV/AIDS antara lain mengalami reaksi emosi pengingkaran, merasa bahwa kenyataan tersebut tidak seharunya terjadi pada mereka, mengapa tidak kepada yang lain. Reaksi pengingkaran tersebut selanjutnya akan berubah menjadi reaksi marah dengan menunjukan perilaku menyalahkan orang lain dan bahkan diri sendiri. Jika kedua reaksi tersebut telah dilewati, maka lama kelamaan akan muncul kesadaran bahwa pengingkaran dan kemarahan tidak akan menyelesaikan masalah, hal ini kemudian berubah menjadi reaksi menerima kenyataan.

Hal yang sama juga disampaikan oleh Yayasan Taratak Jiwa Hati “di awal-awal memang kami melihat adanya goncangan, semacam penolakan dan lain sebagainya, tapi dengan pendampingan lama-lama bisa menerima, ya mau apa lagi kan “. Dari pernyataan di atas, jelas bahwa pengetahuan seseorang terhadap kondisi yang dialami menjadi faktor yang menentukan cepat atau lambatnya penerimaan seseorang akan kondisi HIV. Pada tahap ini perlu pendampingan yang dilakukan oleh pihak yang lebih berpengalaman terhadap HIV baik itu yang dilakukan oleh individu (yang

\footnotetext{
${ }^{7}$ ARV (Obat Anti Retroviral) obat yang diberikan kepada pengidap HIV dan AIDS

${ }^{8}$ VCT (Voluntary Counseling Test) tatalaksana pra pemeriksaan darah pada orang yang potensi tertular HIV, salah satunya dengan melakukan konseling pra test.
} 
lebih tepat adalah keluarga/kerabat) maupun dilakukan oleh lembagalembaga soaial yang ada.

\section{Pengasuhan Anak Terinfeksi HIV dalam Keluarga}

Dalam konteks persoalan HIV/AIDS, gambaran umum kondisi kesehatan anak menjadi pertanda baik atau tidaknya perawatan/pengasuhan anak yang dilakukan oleh keluarga. Dalam penelitian ini terlihat bahwa secara umum kondisi kesehatan anak sangat variatif. Ada yang masih belum mengkonsumsi ARV, ada yang sudah mengkonsumsi ARV dan ada yang sudah di identifikasi infeksi oportunistik yang mengikutinya.

Konsumsi ARV dan Infeksi oportunistik yang mengikuti adalah salah satu variabel untuk melihat penurunan kondisi kesehatan seorang pengidap HIV/AIDS. Obat ARV digunakan untuk mempertahankan tingkat kekebalan tubuh seseorang, sementara infeksi oportunistik adalah penyakit lain yang menyerang pengidap HIV/AIDS manakala kondisi kekebalan tubuhnya menurun. Dalam penelitian ini ditemukan paling banyak anak-anak pengidap HIV mengalami infeksi TB Paru dan terdapat satu orang anak yang mengalami gagal tumbuh kembang.

Tidak banyak hal spesifik yang dilakukan keluarga dalam pengasuhan anak yang terinfeksi HIV. Mereka tetap memperlakukan anak mereka layaknya anak-anak yang lain. Rutinitas keseharian anak juga berlaku pada anak mereka bagi yang sudah sekolah maka setiap pagi selalu diantar oleh orang tuanya, bermain juga dilakukan secara bebas walaupun secara durasi dibatasi. Hal ini dilakukan keluarga untuk tetap menjag kualitas kesehatan anak dan mejauhkan anak dari infeksi kuman/bakteri yang kemungkinan lebih besar jika anak berada dalam lingkungan yang tidak sehat, walau bagaimanapun resiko terkena infeksi lebih besar pada anak yang memiliki riwayat HIV dibanding anak yang tidak memiliki HIV. Seperti pengakuan NP "kalau sudah flu batuk, anak saya sembuhnya lama dibanding anak-anak yang lain".

Beragaman cara dilakukan oleh keluarga dalam mempertahankan kondisi kesehatan anaknya agar tetap maksimal dan yang paling umum adalah menggunakan obat-obatan yang diberikan oleh dokter melalui pemeriksaan rutin, selain itu terdapat satu keluarga yang juga menambhakn dengan pendekatan alternatif seperti yang dilakukan oleh NP dengan menggunakan pendekatan meminum air putih yang banyak. Hal ini diyakini oleh NP mumpuni dalam mempertahankan kondisi kesehatan anaknya.

Pemeriksaan rutin tetap dilakukan oleh keluarga ke pusat-pusat kesehatan rujukan di Padang. Selain untuk melakukan pengambilan obat 
ARV setiap bulan, keluarga juga melakukan konsultasi jika menemukan halhal yang baru selama proses pengasuhan anak. Dalam proses pemeriksaan rutin inilah kadang-kadang dokter memberikan resep tambahan dalam bentuk obat-obatan jenis vitamin yang bermanfaat bagi kesehatan anak. Akan tetapi seringkali ini terasa memberaktan bagi keluarga karena biasanya obat-obatan jenis ini tidak ditanggung oleh BPJS. Seperti yang dikatakan oleh JN, "kami sangat kesulitan apalagi jika sudah berkaitan dengan resep dokter yang tidak ditanggung BPJS, mau gimana lagi memang kondisinya begitu ". Tak banyak pilihan yang bisa dilakukan keluarga untuk hal ini "kadang-kadang kami meminjam uang kepada kenalan, jika tidak dapat ya terpaksa tidak menebus resep" begitu yang diungkapkan oleh JN. Meminjam sejumlah uangkepada tetangga atau kenalan lainnya juga menjadi cara yang dilakukan oleh FN manakala mengalami kesulitan untuk membeli obat-obatan yang tidak masuk kedalam pertanggungan BPJS.

Hal yang tersulit dalam pengasuhan anak terinfeksi HIV adalah kepatuhan meminum obat. Hampir seluruh informan membenarkan hal ini. Seperti yang disampaikan oleh NP,"kadang-kadang ada ngembeknya juga, maklum rasa obat yang dimakan tidak sama dengan obat anak-anak yang lain yang punya rasa buah-buahan, apalagi tidak hanya memamakn sekali dua kali tapi seumur hidup, belum lagi obat untuk infeksi lainnya". Jika kondisi itu terjadi inorman menyatakan tidak bisa berbuat apa-apa kecuali, membiarkan anaknya tidak mengkonsumsi obat hal ini dinyatakan oleh TM 'habis bagaimana lagi, dia tidak suka mau diapakan lagi, saya saja kadangkadang juga muncul bosannya juga, dari pada saya menekan anak saya, biarlah dia sesekali tidak makan obat". Kepatuhan meminum obat memang menjadi salah satu isue yang penting dalam pengasuhan anak HIV/AIDS.

Johana Debora Imelda (2016) dalam artikel penelitiannya yang berjudul Proses Disclosure dan Kondisi PSikososial Anak Dengan HIV/AIDS menyatakan bahwa kepatuhan dalam mengkonsumsi obat menjadi faktor penting yang diperhatikan dalam kualitas hidup anak dengan HIV/AIDS, hal ini penting dijaga salah satu caranya adlah dengan pendampingan tidak hanya darikeluarga tetapi juga dari lembaga-lembaga sosial yang peduli dengan persoalan anak dengan HIV/AIDS.

\section{Keterlibatan Keluarga Luas dalam Pengasuhan Anak}

Anak dengan HIV/AIDS tentu saja membutuhkan keberlanjutan hidup yang lebih baik. Dia tidak akan dapat bertahan hidup dengan segala permasalahannya, baik masalah medis maupun psikososial tanpa ada sistem sosial yang menopang mereka. Salah satu sistem yang diharapkan adalah keluarga. Keluarga dipandang sebagai sebuah sistem yang mampu 
mengendalikan seluruh persoalan yang ada dalam persoalan anak dengan HIV/AIDS ini. Aktor paling penting dalam keluarga ini adalah orang tua.

Hasil penelitian ini memperlihatkan bahwa ibu lebih banyak memainkan peran-peran pengasuhan dari pada bapak. Hanya terdapat 1 informan yang pengasuhan dilakukan oleh sang bapak akan tetapi juga di bantu oleh sang nenek. OLeh karena itu terlihat sekali bahwa pengetahuan dan keterampilan ibu mengenai seluk-beluk HIV/AIDS jauh lebih baik dari sang bapak. Hal ini juga disampaikan oleh Ricko Direktur Yayasan Taratak Jiwa Hati "memang yang paling banyak mengurus anak-anak itu adalah ibunya, kalau pemeriksaan kesehatan dilakukan pasti lebih banyak ibu yang berperan, bapaknya saya lihat sekali-kali aja. Pertemuan-pertemuan di yayasanpun lebih banyak dihadiri ibu-ibu ketimbang bapak-bapak, kalaupun ada bapak-bapak hanya sifatnya menemani dan cenderung pasif, tidak banyak komentar dan terlibat diskusi”.

Lebih jauh diyakini bahwa tidak hanya pentingnya peran keluarga inti dalam pengasuhan anak, akan tetapi keterlibatan keluarga luas/kerabat lainnya seperti, nenek, paman, atau bibi penting artinya dalam fenomena ini. Kehadiran mereka ditengah-tengah persoalan ini sangat berpengaruh dalam proses menunjang kehidupan anak untuk bisa bertahan hidup lebih lama. Selain faktor nutrisi dan pengobatan medis, kehadiran keluarga memiliki peran dalam perawatan anak dengan HIV/AIDS dan merupakan lini utama perlindungan bagi mereka.

Selanjutnya dalam artikel penelitian Johana Debora Imelda (2016) yang berjudul Proses Disclosure dan Kondisi PSikososial Anak Dengan HIV/AIDS menyatakan bahwa Anak dengan HIV/AIDS yang tinggal bersama ibu yang positif, kebiasaan makan mereka lebih sehat karena ibu yang positif mempunyai pengetahuan yang memadai dan lebih memperhatikan kualitas makanan anak-anaknya. Anak yang diasuh dengan keluarga luas cenderung tidak diperhatikan kualitas makanan yang mereka konsumsi karena keterbatasan pengetahuan dan keterbatasan keuangan.

Hal ini sejalan dengan yang disampaikan oleh Friedman (1998) bahwa fungsi keluarga yang juga harus dijalankan oleh keluarga adalah fungsi perawatan kesehatan, yaitu fungsi untuk mempertahankan keadaan kesehatan anggota keluarga. Keluarga diharapkan dapat dan mampu mengenal masalah kesehatan yang dialami oleh anggota keluarga, memutuskan tindakan keperawatan yang tepat dan sesuai kebutuhan, melakukan perawatan yang tepat, menciptakan dan memodifikasi lingkungan yang mendukung kesehatan anggota keluarga, dan dapat memanfaatkan fasilitas kesehatan untuk mencegah dan mengatasi masalah kesehatan. 
Dengan demikian, fungsi dan peran keluarga sangat dibutuhkan oleh semua anggota keluarga khususnya anggota keluarga dengan penyakit kronis guna mendukung peningkatan status kesehatannya.

Keluarga merupakan sasaran utama dalam upaya meningkatkan status kesehatan anggota keluarga. Hal ini disebabkan karena keluarga adalah sumber daya penting untuk memberikan pelayanan kesehatan baik individu dan keluarga. Ketika keluarga menjadi fokus utama untuk intervensi perawatan, efektifitas pelayanan kesehatan menjadi lebih meningkat. Keberhasilan intervensi keperawatan sangat bergantung pada keinginan keluarga berbagi informasi tentang anggota keluarga yang sakit, penerimaan keluarga dan pemahaman keluarga tentang terapi, apakah intervensi cocok dengan praktik harian keluarga, serta apakah keluarga mendukung dan menerapkan terapi yang dianjurkan (Potter dan Perry, 2010).

\section{Dukungan Layanan Kesehatan Pemerintah}

Seiring dengan semakin meningkatnya kasus HIV/AIDS di Indonesia maka salah satu isue strategis pembangunan bidang kesehatan adalah pelayanan dan pengendalian penyakit menular, hal ini juga dilakukan oleh Pemerintah Kota Padang.

Menurut Kepala Dinas Kesehatan Kota Padang, Dr. Ferrymulyani Hamid, M.Biomed saat ini Dinas Kesehatan Kota Padang memiliki program "triple Elimination" pada kelompok ibu hamil, yaitu sebuah program untuk mengeliminasi tiga hal pada ibu hamil yaitu eliminasi HIV, eliminasi TB dan eliminasi Hepatitis A. Secara umum digambarkan bahwa setiap ibu hamil di KOta Padang harus melakukan pemeriksaan tiga aspek eliminasi ini, hal ini dilakukan agar sedini mungkin dikethaui gejala-gejala atau keluhan terkait 3 aspek eliminasi sehingga tenaga medis sedini mungkin juga mampu memberikan pelayanan dan perawatan khusus jika ditemukan hal-hal yang dimaksud dalam program ini. Oleh karena itu, megingat pentingnya program triple elimination ini, maka saat ini seluruh pusat-pusat pelayanan kesehatan milik pemerintah Kota Padang telah mampu melakukan upaya deteksi dini tiga aspek eliminasi tadi.

Lebih lanjut Kepala Dinas Kesehatan Kota Padang menyatakan bahwa saat ini Dinas Kesehatan Kota Padang juga melakukan upaya-upaya pencegahan terhadap penularan HIV pada kelompok anak dan remaja dengan terus mengembangkan kegiatan promosi kesehatan dalam bentuk sosialisasisosialisasi ke sekolah-sekolah dan organisasi kepemudaan, serta dengan mendistribusikan KIE mengenai HIV/AIDS ke seluruh masyarakat. 
Jika dari aspek kesehatan telah banyak hal yang dilakukan oleh Dinas Kesehatan Kota Padang, hal ini tidak di ikuti dengan program dukungan bagi keluarga yang memiliki anak dengan HIV/AIDS, seperti yang disampaikan oleh Kepala Dinas Kesehatan Kotaa Padang berikut ini :

"Kalau Dinas Kesehatan hanya memiliki program-program yang terkait HIV/AIDS seperti yang saya sampaikan tadi. MEngenai program dukungan bagi keluarga kami tidak memiliki kewenangan sampai disitu, barangkali ada di OPD lain. Tetapi tenaga medis kami di lapangan kadang-kadang juga mau tidak mau terlibat dalam upaya-upaya pendampingan terhadap keluarga, tetapi kembali lagi ya...aspeknya sangat medis tentunya. Jika ada hal-hal yang sifatnya sosial kemasyarakatan tentu tidak spesifik." (Wawancara dengan Kepala Dinas Kesehatan Kota Padang, Dr. Ferimulyani Hamid, M.Biomed tanggal 12 September 2018).

Sementara itu alah seorang staf di Yayasan Taratak Jiwa Hati Padang menyatakan "memang belum ada secara spesifik program untuk dukungan keluarga yang memiliki anak dengan HIV/AIDS, jangankan itu untuk anak yang HIV/AIDS itu sendiri saja belum ada format yang tepat untuk membantu intervensinya, banyak hal kami kira yang menyebabkan itu, tetapi ini akan menjadi catatan bagi pemangku kewajiban kedepan"

Mengenai akses terhadap pusat pelayanan kesehatan, seluruh informan menyatakan bahwa belum pernah mengalami perlakuan diskriminatif dari petugas kesehatan yang ada, mereka juga mengakui tidak pernah dipisahkan dalam pelayanan kesehatan, tidak pernah menerima sikapsikap yang merendahkan atau bentuk ketakutan terhadap kondisi mereka. Seperti yang disampaikan oleh TM "tidak pernah mengalami diskrimnasi, semua lancar, tidak ada sikap yang melecehkan atau bentuk lainnya" hal yang sama juga disampaikan oleh NP "saya dan anak dilayani baik kok, biasa saja sama seperti pasien lain".

Berkaca pada pengakuan para informan dapat disimpulkan bahwa seluruh informan dapat mengakses pelayanan kesehatan dengan mudah dan perlakuan petugaspun tidak pernah diskriminatif terhadap mereka. Hal ini membuktikan kepada kita bahwa agaknya literasi pada petugas kesehatan mengenai HIV/AIDS semakin membaik.

\section{Stigma dan Diskriminasi}

Stigma terhadap HIV/AIDS masih cukup tinggi. Tidak mudah bagi masyarakat untuk menerima penderita HIV AIDS hidup secara normal di tengah-tengah mereka. Ketakutan akan terjadinya penularan serta keyakinan 
bahwa penderita akan memberikan kesialan pada lingkungan mereka, merupakan tantangan dalam menangani dampak sosial HIV AIDS. Selain itu hingga saat ini stigama terhadap HIV/AIDS selalu dikaitkan dengan standar moral dan perilaku seseorang, padahan bukan tidak mungkin justru orangorang yang tak bersalah juga tertular HIV/AIDS dari orang lain dengan beragam cara.

Anak-anak penderita HIV/AIDS yang mendapatkan stigma tentu akan dirugikan manakala mereka mengalami penolakan di lingkungan sosial mereka. Penolakan tersebut akan berdampak terhadap kualitas tumbuh kembang anak.

Menyampaikan dan membuka status HIV/AIDS seorang anak juga bukan perkara mudah, selain akan munculnya ketakutan akan penularan virus juga dimungkinkan munculnya diskriminasi terhadap anak. Namun apabila satus HIV mereka tidak disampaikan, maka tidak menutup kemungkinan anak-anak lain disekitar akan terancam tertular melalui transmisi darah walaupun hal tersebut tidak mudah. Sementara pada isu HIV/AIDS dengan penularan dari ibu ke anak, jelas, anak adalah korban karena mereka telah membawa virus ini sejak dilahirkan. Namun mereka tidak dapat menikmati perlakuan yang wajar dari lingkungannya karena menderita HIV positif.

Stigma adalah perilaku maupun kepercayaan yang salah terhadap seseorang ataupun sesuatu. HIV/AIDS terkait stigma secara langsung menunjuk pada orang dengan HIV/AIDS (ODHA) atau pada orang-orang yang dirasa dapat terinfeksi, seperti halnya orang-orang yang mereka cintai, asosiasi tertutup, group sosial dan komunitas. HIV AIDS terkait stigma adalah tantangan terbesar untuk memperlambat penyebaran penyakit. Akibat dari stigma ini akan muncul diskriminasi terhadap penderita. Diskriminasi adalah perlakuan terhadap individu atau kelompok dengan sikap memihak atau prasangka. Diskriminasi sering didefinisikan sebagai bagian dari hak asasi manusia yang akan berpengaruh pada layanan kesehatan, pekerjaan, sistim hukum dan kesejahteraan sosial. Diskriminasi mengekspresikan pemikiran/sikap yang terdapat dalam stigma. Fakta memperlihatkan sebagian besar anggota masyarakat memandang orang dengan HIV/AIDS sebagai pribadi yang tidak bertanggungjawab dan mempermalukan keluarga dan masyarakat. Hal ini tentu saja akan membawa implikasi terhadap bagaimana seseorang akan berperilaku dalam menghadapi HIV/AIDS. Dalam konteks ini, orang mungkin akan memandang HIV/AIDS sebagai hukuman terhadap perilaku amoral, kejahatan, dan lain-lain yang membuat akhirnya hanya sedikit orang yang akan terbuka atas perilakunya. 
Dalam penelitian ini sebanyak enam orang informan menyatakan bahwa tidak pernah mengalami stigma dan diskriminasi selama pengasuhan dan perawatan anak di Padang, akan tetapi dua orang informan pernah memiliki pengalaman diskriminasi sewaktu pengobatan anaknya di salah satu rumah sakit di Jakarta dan Surabaya, "waktu anak saya sakit ada prilaku seperti jijik para perawat memperlakukan anak saya, tapi saya akhirnya komplain" begitu yang disampaikan oleh TM. Ketakutan akan stigma dan diskriminasi diutarakan oleh seluruh informan. Walalupun sampai saat ini mereka belum mengalami hal tersebut, akan tetapi ketakutan itu terus membayangi keluarga.

Akibat dari stigma ini, orang tua, dalam hal ini ibu ataupun bapak, memilih untuk tidak menyampaikan status HIV anak bahkan pada keluarga yang hidup serumah seperti anak yang lebih dewasa dan kerabat lain seperti nenek, paman dan lain-lain. Tindakan lainnya yang muncul dari perilaku keluarga adalah dengan cara melindungi anak dari lingkungannya secara berlebihan, seperti membatasi jam main secara ketat, tidak boleh melakukan kegiatan yang berlebihan dan lain sebagainya.

Pengalaman dari Kartini Ketua IPPI Sumatera Barat adalah ketika pelaksanaan pertemuan kelompok untuk mendiskusikan berbagai hal menyangkut informasi HIV/AIDS,

"pada awal-awal pertemuan agak sulit memang meyakinkan orang tua untuk mengikuti berbagai kegiatan yang kami laksanakan, kalaupun akhirnya mereka mau datang dalam pertemuan tersebut mereka cenderung diam dan tak bersedia menyampaikan pengalaman hidup dan status HIV secara terbuka, kami sangat mengerti akan hal itu, oleh karena itu sebelum mengundang mereka ke pertemuan kami meyakinkan mereka bahwa yang hadir dalam pertemuan adalah para orang tua yang memiliki anak HIV baru setelah itu mereka mau datang"

Ketakutan orang tua cukup beralasan, mereka cemas apabila yang hadir dalam pertemuan terdapat orang-orang yang dikenal dan dengan demikian maka status HIV mereka akan terkuak.

Pada persoalan anak yang terinfeksi HIV, adalah hal yang tidak mudah untuk menyampaikan tentang sikap masyarakat yang menolak kehadiran mereka. Ibarat buah simalakama, ketika status HIV anak dibuka, maka bisa jadi stigma yang ada akan semakin kuat dan perilaku diskriminatif juga semakin nyata. Namun apabila tidak disampaikan, maka dapat menimbulkan kerugian pada lingkungan di sekitar anak (terutama teman- 
teman bermain) juga si anak sendiri. Dari sini jelas bahwa stigma bukanlah hal yang mudah untuk dihadapi apalagi ditanggulangi.

Petingnya pembukaan status HIV pada anak juga disampaikan dalam penelitian yang dilakukan oleh Johana Debora Imelda (2016) menyimpulkan bahwa kondisi psikososial anak dengan HIV/AIDS dipengaruhi oleh beberapa faktor seperti pengetahuan tentang HIV/AIDS, dukungan sosial, dan Pembukaan Status (disclosure) HIV/AIDS pada anak dengan HIV/AIDS. Pengetahuan mengenai HIV/AIDS merupakan hal yang sangat penting karena mereka masih anak-anak dan butuh bimbingan dari pengasuh yang paham dengan baik mengenai HIV/AIDS. Selain itu, dapat disimpulkan bahwa anak dengan HIV.AIDS yang mengetahui statusnya melalui voluntary disclosure lebih baik dalam tingkat kepatuhan minum obat dibanding anak yang mengetahui statusnya melalui unvoluntary disclosure dan anak yang belum tahu tentang statusnya.

Mengingat semakin meningkatnya jumlah anak-anak yang terinfeksi HIV/AIDS maka sudah sepantasnya muncul tata cara dan atata aturan terkait pembukaan status HIV/AIDS karena sampai hari ini belum ditemukan landasan baku bagi berbagai pihak mengenai langkah-langkah untuk pembukaan status HIV/AIDS. Hal ini penting dipikirkan ke depan karena seluruh stakeholder harus mempersiapkan anak dengan HIV/AIDS menjadi generasi yang produktif dan mampu berfungsi sosial dengan baik, bukan dianggap sebagai beban masyarakat

\section{Dukungan Lembaga Masyarakat}

Keluarga yang memiliki anak terinfeksi HIV/AIDS tentu saja mengalami goncangan hebat apalagi dengan kasus penularan vertikal atau dari ibu ke anak. Dalam situasi tidak hanya orang tua dituntut untuk memmperhatikan kualitas kesehatan anak akan tetapi tak boleh dilupakan kondisi orang tua sendiri terutama ibu yang juga mengalami hal yang sama dengan anak yaitu terinfeksi HIV. Dalam situasi ini tentunya dibutuhkan dukungan dari keluarga luas dan komunitas.

Menurut Kepala Dinas Kesehatan Kota Padang dibutuhkan dukungan kolektif dari masyarakat agar keluarga yang memiliki anak HIV/AIDS bisa menjalankan peran-peran pengasuhannya dengan baik, dan jika terdapat keluarga yang memang benar-benar tidak mampu melakukan itu sudah sepatutnya ada semacam panti atau sejenisnya untuk membantu pengasuhan anak dengan HIV/AIDS, baik itu yang diselenggarakan oleh pemerintah maupun lembaga masyarakat. 
Hal ini sejalan dengan apa yang disamaikan oleh FN "saya awalnya memang sangat ketakutan menerima kondisi ini, tetapi lama-lama menjadi terbiasa, menerima, salah satunya kerena bertemu yayasan". Sementara itu JN menyampaikan hal berikut :

"Jujur saya disini tidak punya keluarga, selain keluarga istri. Kepada siapa lagi saya mengadu kan, waktu kami kesulitan kami di bantu oleh yayasan walau sekedar untuk tempat singgah dan makan, jadi kami merasa berhutang budi juga pada yayasan, terutama saya pribadi, kalau tidak ada yayasan entah bagaimana lagi saya."

Informasi yang disampaikan oleh Yayasan Taratak Jiwa Hati bahwa yayasan memang saat ini mempunyai beberapa kegiatan untuk para pengidap HIV/AIDS di Sumatera Barat, beberapa program itu seperti melakukan penjangkauan pada kelompok beresiko, melakukan pendampingan, pemeriksaan kesehatan dan penguatan kapasitas mereka melalui pertemuanpertemuan rutin. Sementara untuk anak-anak dan keluarga juga dilakukan pendampingan kepada anak terutama untuk mendukung kepatuhan minum obat dan jika ditemukan beberapa kondisi keluarga memerlukan kebutuhan finansial yayasan biasanya menggalang donasi.

Ketua IPPI SUmatera Barat juga menyampaikan hal yang sama, "saat ini memang fokus kami ke perempuan positif dan karena ada yang bersattsu ibu dengan anak terinfeksi HIV maka akhirnya mau tidak mau juga mendampingi anak dan keluarga secara umum. Bentuk kegiatan yang dilaksanakan seperti pendampingan dalam pengobatan rutin, diskusi kelompok dan lain-lain. Bahkan tak jarang juga terpaksa mengasuh langsung anak yang sedang perawatan intensif akibat infeksi oportunistik yang dialaminya, seperti yang saat itu peneliti saksikan Ketua IPPI Sumatera Barat mengasuh salah seorang anak JN yang sedang dalam perawatan TB Paru. Keputusan itu diambil karena beberapa kali pengobatan TB Paru anak JN tidak tuntas akibat mengalami putus obat sebagai dampak dari ketidakpatuhan mengkonsumsi obat TB Paru.

Pentingnya dukungan lembaga-lembaga masyarakat juga di amini oleh Kepala Dinas Kesehatan Kota Padang sebagai berikut :

"mereka memang para relawan yang bagus saya kira, mungkin karena beberapa berasal dari latar belakang orang dengan HIV/AIDS, maka jadi lebih mudah merasakan apa yang dirasakan oleh orang lain. Selain itu mereka mudah diterima dalam kelompok orang dengan HIV/AIDS, dengan demikian berbagai informasi dan penguatan lebih mudah dilakukan dibanding jika kita yang 
melakukan, jadi memang dibutuhkan peran serta lembaga-lembaga masyarakat yang bekerja untuk HIV/AIDS"

\section{Nilai Anak}

Anak adalah sesuatu yang berharga dalam hidup, dalam kondisi anak apapun, orang tua selalu mampu menerima, termasuk bagi informan dalam penelitian ini. Seperti yang disampaikan oleh FN "walau bagaimanapun dia darah daging saya, saya akan melakukan apa saja demi kesembuhannya, siapa lagi yang akan merawat dan mengasuh dia kalau bukan saya". Lain lagi yang disampaikan oleh LN,

"saya harus merawat dan mengasuh dia sebaik mungkin, dia harta yang sangat berharga bagi kami dan keluarga. Kami ingin menebus kesalahan kami, akibat kesalahan kami dia menderita, kami yakin suatu saat ada jalan keluar untuk kesembuhan".

Apa yang disampaikan oleh dua informan diatas juga disampaikan oleh informan-informan lainnnya. Bagi mereka anak dengan HIV/AIDS tetaplah bernilai, informan meyakini bahwa kondisi yang terjadi saat ini akibat kelalaian mereka sebagai orang tua, sehingga menurut mereka sudah sepantasnya mereka menebus kesalahan dengan melakukan apa saja selama proses pengasuhan anak.

Hal ini sejalan dengan apa yang disampaikan Joshi dan MacClean (1997) seperti yang dikutip dalam Putri(2006), nilai anak merupakan persepsi dan harapan orangtua terhadap anakberdasarkan potensi yang dimiliki anak. Anak dipandang sebagai sumberdayayang sangat berharga dan tahan lama oleh karena itu anak memiliki nilai psikis sekaligus nilai materi sehingga orangtua menganggap anak merupakan nilai investasi dimasa depan yang efisien. Investasi pada anak diwujudkan dengan pengasuhan. Lebih lanjut dinyatakan bahwa penilaian orangtua akan mempengaruhi cara mereka memperlakukan anak. Anak memiliki nilai universal namun nilai anak tersebut sangat dipengaruhi oleh faktor sosio kultural dan lain-lain.

\section{PENUTUP}

Melihat pengalaman keluarga dalam melakukan pengasuhan anak yang terinfeksi HIV/AIDS, maka untuk dapat meningkatkan kualitas pengasuhan dan perawatan anak dimaksud perlu dikembangkan beberapa pemahaman sebagai berikut, pertama, anak yang terinfeksi HIV harus diposisikan sebagai korban, dengan demikian jika posisi anak sebagai korban maka membahas anak yang terinfeksi HIV harus lah dari perspektif 
perlindungan, bagaimana mengerahkan segala upaya untuk memaksimalkan pengasuhan dan perawatan terhadap anak agar memiliki kualitas kesehatan yang baik, memperpanjang peluang untuk hidup serta memenuhi hak-hak fundamentalnya sebagai anak. Oleh karena itu penting untuk terus melakukan edukasi dan memperkuat literasi masyarakat dalam konteks ini. Kedua, Pemerintah memperkuat dukungan bagi keluarga yang melakukan pengasuhan anak yang terinfeksi HIV dengan berbagai program spesifik tidak hanya layanan kesehatan tetapi juga layanan penguatan pengasuhan melalui kunjungan rumah. Hal ini dapat dilakukan melalui kolaborasi dengan lembaga-lembaga swadaya masyarakat yang ada karena diyakini para aktivis HIV/AIDS yang ada di lembaga swadaya masyarakat yang ada mumpuni dalam melakukan penjangkauan dan pendekatan kepada keluarga dengan anak HIV/AIDS. Ketiga, Adanya dukungan program penguatan bagi keluarga luas dan kerabat lainnya dari anak yang terinfeksi HIV/AIDS untuk mempersiapkan penerimaan status HIV salah seorang anggota keluarganya seraya mempersiapkan dukungan apa yang akan diberikan setelah itu untuk meningkatkan kualitas kesehatan anggota keluarganya. Keempat, Pemerintah mempersiapkan jaminan sosial dan jaminan pengasuhan bagi anak-anak yang terinfeksi HIV yang berasal dari keluarga kurang mampu dalam bentuk pusat rehabilitasi anak. Kelima, Penting artinya disiapkan intervensi sosial untuk mempersiapkan proses disclosure keluarga terhadap anggota keluarganya yang terinfeksi HIV/AIDS untuk memunculkan dukungan sosial bagi pengasuhan bagi anak yang berkelanjutan, dengan demikian diharapkan kualitas kesehatan anak dengan HIV/AIDS dapat dipertahankan.

\section{DAFTAR PUSTAKA}

Allen, D., \& Marshall, E.S. 2008. Childrenm With HIV/AIDS: With unique palliative care. Journal of Hospice and Palliative Nursing, 10(6), 359-367

BPS. 2018. Padang Dalam Angka. Padang

Dinas Kesehatan Kota Padang. 2018. Laporan Tahunan Dinas Kesehatan Kota Padang tahun 2017. Padang

Fabanjo, Ivvone Junita. 2012. Pengalaman Keluarga Merawat Anak dengan HIV/AIDS yang menjalani Terapi ARV Pada Klinik VCT di RSUD Manokwari Papua Barat. Fakultas Ilmu Keperawatan, Program Magister Ilmu Keperawatan: Universitas Indonesia

Imelda, Johana Debora \& Arini Dwi Deswanti. 2016. Proses Disclosure dan Kondisi Psikososial ANak dengan HIV/AIDS. Jurnal Ilmu Kesejahteraan Sosial, Universitas Indonesia. Jakarta. 
James, S.R \& Ashwill, JW. 2007. Nursing Care of Children Principle \& Practice (3th.ed). St. Louis, Missouri:Saunders Elsier

Potter. P.A \$ Perry, A.G. 2010. Fundamental of Nursing : Fundamental Keperawatan. Edisi 7. Jakarta: Salemba Medika

Undang-Undang No. 23 tahun 2002 seperti yang telah diubah dengan Undang-Undang No. 35 tahun 2014 Tentang Perlindungan Anak.

http://www.kebijakanaidsindonesia.net/id/artikel/38-info-proyek-projectinfo/progress-report/888-strategi-dan-aksi-nasional-penanggulangan-aids$\underline{2015-2019}$ 
194| Fokus : Jurnal Kajian Keislaman dan Kemasyarakatan, Vol 4, No. 2, Nov 2019 